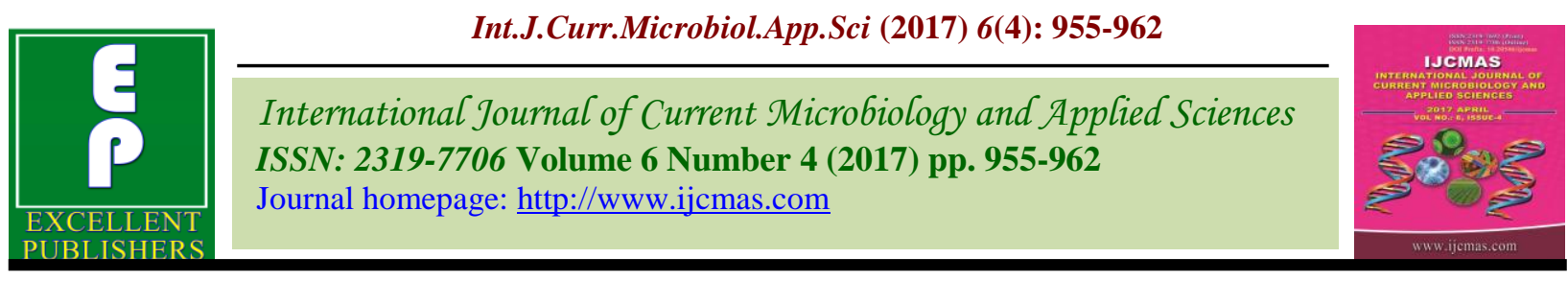

Review Article

https://doi.org/10.20546/ijcmas.2017.604.120

\title{
Biofortification: A Novel Approach for Enrichment of Cereal Grains with $\mathrm{Zn}$ and Fe
}

\section{Hari Mohan Meena ${ }^{1 *}$, R.P. Sharma ${ }^{2}$, Dharam Singh Meena ${ }^{3}$, Swapana Sepehya ${ }^{2}$ and Dinesh Kumar Yadav ${ }^{4}$}

\author{
${ }^{1}$ Department of Soil Science and Agricultural Chemistry, GKVK, UAS, \\ Bengaluru-560065 Karnataka, India \\ ${ }^{2}$ Department of Soil Science, CSKHPKV, Palampur, Himachal Pradesh, India \\ ${ }^{3}$ Department of Agronomy, GKVK, UAS Bengaluru-560065 Karnataka, India \\ ${ }^{4}$ Division of Agricultural Chemicals, IARI, New Delhi, India \\ *Corresponding author:
}

\begin{tabular}{|c|c|}
\hline & A B S T R A C T \\
\hline & \multirow{5}{*}{$\begin{array}{l}\text { Zinc and iron deficiencies in human nutrition are widespread in developing } \\
\text { countries of the world where cereal crops are the major staple food. Effects are } \\
\text { therefore underway to develop cereal genotypes with grains denser in } \mathrm{Zn} \text { and Fe } \\
\text { by traditional plant breeding or using genetic engineering techniques. This } \\
\text { approach requires a long period and adequate funds. However, the products of } \\
\text { genetic engineering are not well accepted in many countries. Agronomic } \\
\text { biofortification is the easiest and fastest way for biofortification of cereal grains } \\
\text { with } \mathrm{Zn} \text { and Fe. Agronomic biofortification is the only way to reach the poorest of } \\
\text { the poor rural masses, which will never have money to buy mineral supplements. } \\
\text { Foliar application is better and requires lesser amount of Fe and Zn fertilizers than } \\
\text { their soil application. Zinc and iron application increases concentration in } \\
\text { produces as well as grain yield under nutrient deficient soil. }\end{array}$} \\
\hline Keywords & \\
\hline $\begin{array}{l}\text { Agronomic } \\
\text { biofortification, } \\
\mathrm{Zn} \text { and Fe, } \\
\text { Cereal Grains }\end{array}$ & \\
\hline Article Info & \\
\hline $\begin{array}{l}\text { Accepted: } \\
\text { 06 March } 2017 \\
\text { Available Online: } \\
10 \text { April } 2017\end{array}$ & \\
\hline
\end{tabular}

\section{Introduction}

Zinc and iron are essential micronutrients for human health and deficiency of these micronutrients leads to malnutrition and diseases. Cereals are staple food in most developing countries of Asia and Africa, where they may contribute as much as 75per cent of the dietary energy. Dietary deficiency of essential micronutrients such as zinc $(\mathrm{Zn})$ and iron $(\mathrm{Fe})$ affects more than two billion people's worldwide mostly pregnant women and children below the age of five year, who suffer from severe acute malnutrition.
The current statistics of nutritional deficiencies highlights the fact that "green revolution" provided only a short-term solution to overcome the problem of hunger. It definitely increased the production of food but nutritional aspect was lacking. The peoples of developing country dependence on staple food crops such as rice, maize and wheat has proved insufficient solution to the problem of hunger. Lesser attention on production of non-staple foods (e.g. fruits and vegetables) lead to a vicious circle of less 
availability, more requirement and high prices that ultimately created a new giant problem of hidden hunger (Johns and Eyzaguirre, 2007).

Hidden hunger maybe defined as overall poor quality of nutrition, that is, individual may eat enough calories to live, but the basic diet fails to provide sufficient levels of crucial vitamins and minerals needed for the mental and physical health (Cakmak, 2008). Hidden hunger impairs the mental and physical development of children and adolescents and can result in lower IQ, stunting and blindness; women and children are especially vulnerable. Hidden hunger also reduces the productivity of adult men and women due to increased risk of illness and reduced work capacity (World Health Organisation, 1995).More than 90 per cent of world's stunted children live in Asia and Africa with 36 percent and 40 per cent as rates of stunting and is considered as an economic issue (Bhullar and Gruissem, 2013).

According to World Health Organisation reports 3 billion peoples worldwide are suffering from micronutrients deficiency and 2.5 billion populations of the world are suffering from Zinc deficiency and 1.6 billion populations suffer from Iron deficiency.

\section{Functions and Deficiency of Fe and $\mathrm{Zn}$ in Humans}

\section{Iron}

$\mathrm{Fe}$ is the key micro mineral nutrient in humans. It is the most important component of haemoglobin and involved in oxygen transport and storage. About 85per cent of Fe in human body is present as a constituent of two heme proteins, namely, haemoglobin which is responsible for the transport of oxygen from the lungs to other parts of the body and myoglobin that stores oxygen in the muscles (Bell and Dell, 2008).
The clinical deficiency symptoms include anemia, fatigue, weakness, and dizziness, reduced intellectual performance and reduced work capacity (Lynch, 2003). The recommended daily allowance (RDA) (mg Fe day $^{-1}$ ) is 10 for children (4-8 years), 8 for adult males, and 18 for adult females (USFNB, 2001).

\section{Zinc}

Zn plays a key role in physical growth and development, the functioning of the immune system, reproductive health, sensory functions and neurobehavioral development. $\mathrm{Zn}$ is an integral component of zinc finger proteins that regulate DNA transcription (Levenson and Morris, 2011). $\mathrm{Zn}$ is the only metal to be involved in all six classes of enzymes: oxidoreductases, transferases, hydrolases, lysases, isomerases and ligases (Barak and Helmke, 1993). Zn ions are also neurotransmitters and are present in the cells of the salivary glands, prostrate and immune system (Herschfinkel et al., 2007).

$\mathrm{Zn}$ is a "Type 2" nutrient, which means that its concentration in blood does not decrease in proportion of the degree of deficiency (Alloway, 2009).As a result, physical growth slows down and excretion is reduced to conserve $\mathrm{Zn}$. Thus, children suffering from $\mathrm{Zn}$ deficiency have reduced linear growth (stunting) (Graham, 2008). International Zinc Association report concludes that 49 per cent of world's population is affected by zinc deficiency with symptoms like growth and sexual immaturity, hypogonadism, hypospermia, alopecia, skin rashes, slow healing of wounds, immune-deficiencies, behavioural disorders, night blindness, and loss of appetite. $\mathrm{Zn}$ is also essential for regulating intestinal absorption of $\mathrm{Fe}$ and sufficient quantity of $\mathrm{Zn}$ along with $\mathrm{Fe}$ in human body is crucial for treating $\mathrm{Fe}$ deficiency anemia (Graham et al., 2012). The 
RDA (mg Zn day ${ }^{-1}$ ) is 5 for children (48years), 11 for adult males, and 8 for adult females (USFNB, 2001).

\section{Global prevalence of micronutrient deficiencies}

According to a World Health Organization report on the risk factors responsible for development of illnesses and diseases in humans, $\mathrm{Zn}$ deficiency ranks $11^{\text {th }}$ among the 20 most important factors in the world. $\mathrm{Zn}$ and Fe deficiency ranks $5^{\text {th }}$ and $6^{\text {th }}$ respectively, among the 10 most important factors in developing countries (Cakmak, 2008).

The regions with Fe-deficient soils are also the regions where $\mathrm{Fe}$ and vitamin $\mathrm{A}$ deficiency in human beings is widespread, for example in India, Pakistan, China, Bangladesh, Central Africa, Iran and Turkey. It is, therefore, not surprising why a widespread Fe deficiency in human beings generally occurs in the regions where soils have $\mathrm{Fe}$ deficiency problem and cereals are major source of daily calorie intake (Cakmak, 2008).

The regions with $\mathrm{Zn}$-deficient soils are also the regions where $\mathrm{Zn}$ deficiency in human beings is widespread, for example in India, Pakistan, China, Iran and Turkey. Possibly, there are many other regions or countries where $\mathrm{Zn}$ deficiency problem has not been reported or diagnosed (Alloway et al., 2004).

\section{Status of micronutrients in Indian soil}

Singh and Behera (2011) analysed three lakh soil samples from different sites of India and reported that 49 per cent soil samples soils were deficient in $\mathrm{Zn}, 12$ per cent in Fe, 3 per cent in $\mathrm{Cu}, 5$ per cent in $\mathrm{Mn}, 33$ per cent in $\mathrm{B}$ and 13 per cent in Mo. It might be due to green revolution has provided nutritional security and food sufficiency in the country through increased irrigation facility, introduction of high yielding varieties and increased use of fertilizers and plant protection measures. However, all these conditions favoured cereal based cropping systems, decrease in use of organic manures and crop residues, which in turn have exhausted the inherent pools of micronutrients in the soil. Thus in the regions where there is a widespread deficiency of micronutrients, it therefore becomes critical for achieving sustainable high crop production.

\section{Weapons to fight against micronutrients malnutrition:}

Supplementation: Supplements are highly concentrated vitamins and minerals produced by pharmaceutical manufacturers in the form of capsules, tablets or injection.

Dietary diversification: The cultivation of a variety of staple food crops such as fruits and vegetables with a high nutrient content that can be produced better consumer behaviour.

Commercial fortification: Fortify food with essential nutrients at the time of food processing and also it is the practices of increasing the content of essential micronutrients in food.

These methods cannot thoroughly solve the malnutrition problem because they only have temporary role in malnutrition and it's have high expensive cost. These methods also fail to reach poorest segments of the general peoples who are at the high risk of micronutrient deficiency.

Bio fortification: It is derived from Greek word "bios" means "life" and Latin word "fortificare" means "making strong". Bio fortification is the process by which the nutritional quality of food crops is improved through agronomic practices, conventional plant breeding or modern biotechnology approaches. 
Fig.1 Approaches for bio fortification of staple food grains

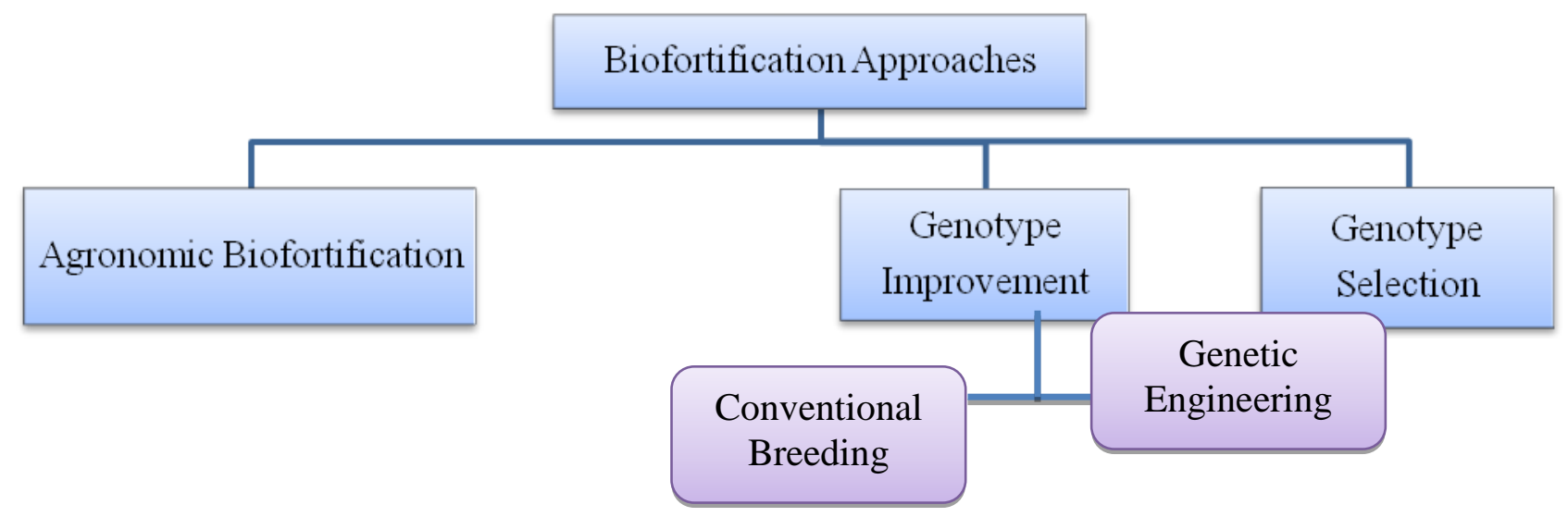

It differs from ordinary fortification because it focuses on making plant foods more nutritious as the plants are growing, rather than having nutrients added to the foods when they are being processed. This is an improvement on ordinary fortification when it comes to providing nutrients for the rural poor, who rarely have access to commercially fortified foods. As such, biofortification is seen as an upcoming strategy for dealing with deficiencies of micronutrients in the developing world

\section{Selective breeding}

Using this method, plant breeders search seed or germplasm banks for existing varieties of crops which are naturally high in nutrients. They then crossbreed these high-nutrient varieties with high-yielding varieties of crops, to provide a seed with high yields and increased nutritional value. Crops must be bred with sufficient amounts of nutrients to have a measurable positive impact on human health. As such, they must be developed with the involvement of nutritionists who study whether the consumers of the improved crop can absorb the extra nutrients and the extent to which storage, processing and cooking of the crops affect their available nutrient levels. This method is prevalent at present, as it is quicker, cheaper, and less controversial than genetically engineering crops. For example, Harvest Plus, a major NGO in the development of biofortified crops primarily use conventional breeding techniques and have not yet spent more than $15 \%$ of their research budget on genetically modified crops when conventional methods fail to meet nutritional requirements.

\section{Biofortification through conventional breeding}

Plants often show genetic variation in essential nutrient content, which then allows breeding programs to be used to improve the levels of minerals and vitamins in crops. Conventional breeding has several significant disadvantages when compared to transgenic approaches. Breeding strategies rely on the sometimes limited genetic variation present in the gene pool. In some cases, this can be overcome by crossing to distant relatives and thus moving the trait slowly into the commercial cultivars. Such a strategy could be used to improve selenium levels in wheat, because today's bread wheat shows little variation in selenium content whereas wild wheat has higher levels.

\section{Transgenic approaches for biofortification}

Biofortification of cereal crops with zinc and $\mathrm{Fe}$ can be achieved by transgenic 
modification. Transgenic approaches could be a further option in improving food crops with $\mathrm{Zn}$ and $\mathrm{Fe}$.

The ability to rapidly identify and characterize gene function and then utilize these genes to engineer plant metabolism has been a driving force in recent bio fortification efforts. This was made possible by the rapid development of whole-genome sequencing, high through put physical mapping, global gene expression analysis and metabolite profiling in a variety of organisms. Currently, impressive progress is being made in developing transgenic plant genotypes with increased concentrations of $\mathrm{Zn}$ and $\mathrm{Fe}$ and also increased phyto availability of mineral elements in the soil, their uptake from the rhizosphere, translocation to the shoot and accumulation in edible tissues (White \& Broadley, 2005 and Zhu et al., 2007).

Several researches have investigated the role of ferritin protein in seed accumulation of $\mathrm{Fe}$ and $\mathrm{Zn}$. Ferritin is a major Fe protein existing in most living organisms (Harrison and Arosio, 1996). Vasconcelos et al., (2003) reported that over expression of soybean ferritin genes in rice was effective in increasing both $\mathrm{Fe}$ and $\mathrm{Zn}$ concentrations of seeds. Transforming rice with ferritin gene from soybean (Qu et al., 2005) or French bean (Lucca et al., 2006) increased grain $\mathrm{Zn}$ and $\mathrm{Fe}$ concentrations.

\section{Agronomic biofortification}

Agronomic biofortification is the easiest and fastest way for biofortification of cereal grains with $\mathrm{Fe}, \mathrm{Zn}$, or other micro mineral nutrients in developing Asian and African countries, where cereals are the staple food. Agronomic biofortification is the only way to reach the poorest of the poor rural masses, which will never have money to buy mineral supplements nor can afford to improve the components of their diet by incorporating animal products.

Imran and Rehim (2016) reported that phytate concentration in grain decreased 60percent by banding + foliar, 33percent by broadcasting + foliar and 16.54percent by banding as compared to control. Phytate is a main $\mathrm{P}$ storage compound in cereal grain and it performs as a metal chelator in the intestine of human; hence, obstructs the bioavailability of dietary nutritional $\mathrm{Zn}$ in humans. It might be yield dilution effect as phytate concentration was primarily decreased with $\mathrm{Zn}$ fertilization alongside by increase in grain yield.

Imran and Rehim (2016) estimated Zn bioavailability was maximum of $2.40 \mathrm{mg} \mathrm{Zn}$ for $300 \mathrm{~g}$ maize grain (52\% than control) by banding + foliar $\mathrm{Zn}$ fertilization. After banding + foliar $\mathrm{Zn}$ application, increase in estimated $\mathrm{Zn}$ bioavailability was of 43 per cent broadcasting + foliar, 34.5 per cent by banding and 25 percent by foliar and 18.6 per cent by broadcasting $\mathrm{Zn}$ fertilization, respectively as compared to control.

Wei et al., (2012) reported that the concentration of $\mathrm{Zn}$ in brown rice was increased from $30.28 \mathrm{mg} \mathrm{kg}^{-1}$ in the control, to $33.75 \mathrm{mg} \mathrm{kg}^{-1}$ by foliar Zn-EDTA application, to35.07 mg kg-1 by foliar Zn-Citrate application, to $38.45 \mathrm{mg} \mathrm{kg}^{-1}$ by foliar $\mathrm{ZnSO}_{4}$ application, to $39.84 \mathrm{mg} \mathrm{kg}^{-1}$ by foliar $\mathrm{Zn}-\mathrm{AA}$ application. It might be due to the different capacity of leaf penetration of different forms of foliar applied $\mathrm{Zn}$ fertilizers. Foliar fertilizer with low molecular weight like $\mathrm{Zn}-\mathrm{AA}$ and $\mathrm{ZnSO}_{4}$ might be easily penetrated into the leaves than those have higher molecular weight like Zn-EDTA and Zn- Citrate fertilizers.

Bharti et al., (2013) reported that the application of combined soil + foliar application of $\mathrm{Zn}$ fertilizer significantly 
increased the grain $\mathrm{Zn}$ content as compared to other treatments. It might be due to increasing the $\mathrm{Zn}$ levels and also obtained lowest values of phytic acid because phytic acid is a $\mathrm{P}$ storage compound and there for a greater $\mathrm{P}$ uptake might be a reason for an antagonistic relationship between phytic acid and $\mathrm{Zn}$ nutrition.

Shivay and Prasad (2014) found that the combined soil + foliar treatment, and always significantly superior to all other treatments. Soil application as $\mathrm{Zn}$-coated urea was nearly always statistically higher than application as $\mathrm{Zn}$ sulphate. All $\mathrm{Zn}$ treatments for agronomic biofortification of $\mathrm{Zn}$ in corn grain as well as in stover were in the following order: $5 \mathrm{~kg}$ soil $+1 \mathrm{~kg}$ foliar $>1 \mathrm{~kg}$ foliar $>2.83 \mathrm{~kg}$ as Zn-coated urea to soil $>5 \mathrm{~kg}$ soil.

Shivay et al., (2015) reported that soil application of $\mathrm{ZnSHH}$ or $\mathrm{Zn}$-EDTA significantly increased the $\mathrm{Zn}$ concentration in grain of rice crop over NPK fertilization, which were at par with two or three applications of $0.2 \%$ solutions of $\mathrm{ZnSHH}$ or Zn-EDTA or one or two applications of $0.5 \%$ solutions of $\mathrm{ZnSHH}$ or $\mathrm{Zn}$-EDTA.

A single application of $0.2 \%$ of $\mathrm{ZSHH}$ or $\mathrm{Zn}$-EDTA was inferior to soil application of $\mathrm{Zn}$ and did not significantly increase $\mathrm{Zn}$ concentration in rice grain. In both the years of study $\mathrm{Zn}$ application either to soil or foliage significantly increased ZnMEI over no fertilizer control.

Singh et al., (2013) reported that three foliar sprays of $\mathrm{FeSO}_{4} \cdot 7 \mathrm{H}_{2} \mathrm{O}$ with 0.5 per cent and 1 per cent levels at different growth stages of rice crop (maximum tillering, pre-anthesis and post-anthesis stages) significantly increased $\mathrm{Fe}$ concentration in brown rice of different rice cultivars as compared to control but results shown by PR113 cultivar were non-significant.
Zhang et al., (2008) reported that combined application of foliar $\mathrm{Fe}$ (II)-AA and $\mathrm{B}$ recorded highest concentration of $\mathrm{Fe}$ in polished rice as compared to the control. Addition of $\mathrm{B}$ in foliar Fe-containing solutions spray did not increase Fe content in polished rice. However, whether B was added in Fe containing solutions or not, foliar Fe(II)AA spray increased significantly the concentration of $\mathrm{Fe}$ in polished rice

Aciksoz et al., (2011) reported that highest iron concentration in grain with the application of $\mathrm{FeSO}_{4}+$ Urea and at par with FeEDTA + Urea and Fe EDDHA + Urea as compare to over treatments.

In conclusion, zinc and iron are essential micronutrients for human health and deficiency of these micronutrients leads to malnutrition and diseases. Methods like fortification, supplementation and dietary diversification definitely play a significant role in countering the hidden hunger. However, they do carry some serious limitations, like the expenses involved, limited access, short-term approach, nonavailability in abundance, and failure to reach all individuals, which limit the extent of its success.

Agronomic biofortification is a win-win approach for developing countries, where cereals are the staple food. From the biofortification viewpoint, foliar application is better and requires lesser amount of $\mathrm{Fe}$ and $\mathrm{Zn}$ fertilizers than their soil application. Zinc and iron application increases concentration in produces as well as grain yield under nutrient deficient soil.

\section{Acknowledgement}

We thanks to the Department of Soil Science and Agricultural Chemistry, University of Agricultural Sciences, GKVK, Bengaluru, 
Karnataka (India) for allotted Doctoral Seminar to me on Biofortification which as an initial framework for this review and thanks to all $\mathrm{c} 0$-authers for their valuable edition and correction based on their specialized subject.

\section{References}

Aciksoz, S.B., Yazici, A., Ozturk, L. and Cakmak, I. 2011. Biofortification of wheat with iron through soil and foliar application of nitrogen and iron fertilizers. Plant Soil, 349: 215-25.

Alloway, B.J. 2004. Zinc in soils and crop nutrition. IZA Publications. International Zinc Association, Brussels, pp. 1-116.

Alloway, B.J. 2009. Soil factors associated with zinc deficiency in crops and humans. Environ. Geochem. Health, 31: 537-548.

Barak, P. and Helmke, P.A. 1993. The chemistry of zinc. In: Robson, A.D. (Ed.), Zinc in Soils and Plants. Kluwer Academic Publishers, Dordrecht.

Bell, D.W. and Dell, B. 2008. Micronutrients for sustainable food, feed, fibre and bioenergy products. Int. Fertilizer Industry Association, Paris, p. 175.

Bharti, K., Pandey, N., Shankhdhar, D., Srivastava, P.C. and Shankhdhar, S.C. 2013.Improving nutritional quality of wheat through soil and foliar zinc application. Plant Soil Environ., 8: 348352.

Bhullar, N.K. and Gruissem, W. 2013. Nutritional enhancement of rice for human health: The contribution of biotechnology. Biotechnol. Adv., 31: 5057.

Cakmak, I. 2008. Enrichment of cereal grains with zinc: Agronomic or genetic biofortification. Plant Soil, 302: 1-17.

Graham, R.D. 2008. Micronutrient deficiencies in crops and their global significance. In: Alloway, B.J. (Ed.),
Micrnutrient Deficiencies in Global Crop Production. Springer, Dordrecht, The Netherlands.

Graham, R.D., Knez, M. and Welch, R.M. 2012. How much nutritional iron deficiency in humans globally is due to an underlying zinc deficiency? $A d v$. Agron., 115: 1-40.

Harrison, P.M. and Arosio, P. 1996. Molecular properties, iron storage function and cellular regulation. Biochem. Biophys Acta, 1275: 161-203

Herschfinkel, M., Siverman, W.F. and Sekler, I. 2007. The zinc sensing receptor, a link between zinc and cell signalling. Mol. Med., 13: 331-336.

Imran, M. and Rehim, A. 2016. Zinc fertilization approaches for agronomic biofortification and estimated human bioavailability of zinc in maize grain. Archives of Agronomy and Soil Sci., 1: 106-116.

Johns, T. and Eyzaguirre, P.B. 2007. Biofortification, biodiversity and diet: A search for complementary applications against poverty and malnutrition. Food Policy, 32: 1-24.

Levenson, C.W. and Morris, D. 2011. Zinc and neurogenesis: making new neurons from development to adulthood. $A d v$. Nutr., 2: 96-100.

Lucca, P., Poletti, S. and Sautter, C. 2006. Genetic engineering approaches to enrich rice with iron and vitamin A. Physiol. Plant, 126: 291-303.

Lynch, S.R. 2003. Iron deficiency anaemia. In: Benjamin, C., Paul, F., Luiz, T. (Eds.), Encyclopaedia of Food Sciences and Nutrition. Academic Press, Amsterdam, pp. 215-320.

Qu, L.Q., Yoshihara, T., Ooyama, A., Goto, F. and Takaiwa, F. 2005. Iron accumulation does not parallel the high expression level of ferritin in transgenic rice seeds. Planta, 222: 225-233.

Singh, M.V. and Behera, S.K. 2011. AIRCP 
on micro and secondary nutrients and pollutant elements in soil and plants- A Profile, Res. Bull., 10: 1-57 (IISS, Bhopal).

Singh, P., Dhaliwal, S.S. and Sadana, U.S. 2013. Iron enrichment of paddy grains through ferti-fortification. J. Res. Punjab Agri. Univ., 50: 32-38.

Shivay, Y.S., Prasad, R., Kaur, R. and Pal, M. 2015. Relative efficiency of zinc sulphate and chelated zinc on zinc biofortification of rice grains and zinc use-efficiency in basmati rice. Proc. Natl. Acad. Sci., India, Sect. B. Biol. Sci., DOI 10.1007/s40011-015-0544-7.

Shivay, Y.S. and Prasad, R. 2014. Effect of source and methods of zinc application on corn productivity, nitrogen and zinc concentrations and uptake by high quality protein corn (Zea mays). Egyptian J. Biol., 16: 72-78.

USFNB. 2001. Dietary reference intake for Vitamin A, Vitamin K, Arsenic, Boron, Chromium, Copper, Iodine, Iron, Manganese, Molybdenum, Nickel, Silicon, Vanadium and Zinc. US Food and Nutrition Board, National Academy Press, Washington, DC.

Vasconcelos, M., Datta, K., Oliva, N.,
Khalekuzzaman, M., Torrizo, L., Krishnan, S., Oliveria M., Goto, F. and Data, S.K. 2003.Enhanced iron and zinc accumulation in transgenic rice with the ferritin gene. Plant Sci., 164: 371-378.

Wei, Y., Shohag, M.J.I. and Yang, X. 2012. Biofortification and bioavailability of rice grain zinc as affected by different forms of foliar zinc fertilization. PLoS ONE, 7: e45428. doi:10.1371/journal.pone.0045428.

White, P.J. and Broadley, M.R. 2005.Biofortifying crops with essential mineral elements. Trends in plant Sci., 10: 586-593.

World Health Organisation. 1995. Global prevalence of vitamin A deficiency micronutrient deficiency information system working paper No. 2. WHO reference number: WHO/NUT/95.3

Zhang J., Wang, M., Wu, L., Wu, J. and Shi, C. 2008. Impacts of combination of foliar iron and boron application on iron biofortification and nutritional quality of rice grain. J. Plant Nutri., 31: 15991611.

Zhu, C. 2007. Transgenic strategies for the nutritional enhancement of plants. Trends Plant Sci., 12: 548-555.

\section{How to cite this article:}

Hari Mohan Meena, R.P. Sharma, Dharam Singh Meena, Swapana Sepehya and Dinesh Kumar Yadav. 2017. Biofortification: A Novel Approach for Enrichment of Cereal Grains with Zn and Fe. Int.J.Curr.Microbiol.App.Sci. 6(4): 955-962. doi: https://doi.org/10.20546/ijcmas.2017.604.120 